\title{
The sero-prevalence of Toxoplasma gondii in British marine mammals
}

\author{
Dan Forman/ ${ }^{+}$, Nathan West, Janet Francis, Edward Guy \\ Conservation Ecology Research Team, Institute of Environmental Sustainability, School of the Environment and Society, \\ Swansea University, Singleton Park, Swansea, SA2 8PP, UK
}

Serum samples from 101 stranded or bycatch cetaceans from British waters were screened for Toxoplasma gondii-specific antibodies using the Sabin Feldman Dye Test. Relatively high seropositivity was recorded in shortbeaked Delphinus delphis and this study presents the first documented case of Toxoplasma in a humpback whale Megaptera novaeangliae.

Key words: cetacean - conservation - environmental contamination - protozoa - toxoplasmosis

Toxoplasma gondii is a globally ubiquitous, Apicomplexan protozoan parasite, capable of infecting all warm blooded animals (Wong \& Remington 1993). Toxoplas$m a$ is a zoonotic parasite responsible for toxoplasmosis, a disease which can affect the survival of many freeliving mammalian species. The only known definitive hosts for T. gondii are members of the Felidae (cat) family. It has frequently been demonstrated that wild animals are important reservoirs of many infectious diseases (e.g. SARS, H5N1 Avian influenza) and play an important role in transmission and disease ecology (Simpson 2002). We, therefore consider it essential that baseline measurements of $T$. gondii prevalence and occurrence are determined in wild animals in order to understand their role in T. gondii epidemiology.

Previously, Toxoplasma studies in wild animals has been restricted to terrestrial species, however, an increasing area of research has focused on marine mammals. Of particular concern is the effect on populations of endangered marine mammals such as sea otters (Enhydra lutris nereis), a mustelid species in which toxoplasmosis has been linked to many instances of mortality on the Western seaboard of the United States. T. gondii positive free-living marine mammals have been identified in many marine ecosystems including the Eastern, Central and Western Pacific, Western Atlantic and Mediterranean (Dubey et al. 2003). This study presents the initial findings of serological screening from a range of cetacean species inhabiting the Northeastern Atlantic and provides the first documented cases of positive Toxoplasma in this marine region.

\section{MATERIALS AND METHODS}

Sera samples from 101 individual cetaceans were obtained by postmortem examination of animals stranded in England and Wales between 2001-2003. All postmortem examinations were conducted according to stan-

+ Corresponding author: d.w.forman@swansea.ac.uk

Received 10 October 2008

Accepted 4 December 2008 dardised methodology (Law 1994) by staff at the Institute of Zoology, London. Sera were analyzed using the Sabin Feldman Toxoplasma Cytoplasma Modifying Antibody Dye Test at the Toxoplasma Reference Unit (TRU 2007), National Public Health Service for Wales, Singleton Hospital, Swansea, United Kingdom, according to the TRU protocol (TRU 2007). Titers deemed positive at $1 / 4\left(\geq 2 \mathrm{IU} \mathrm{mL}^{-1}\right)$ according to TRU standards were classified as positive results. To facilitate analysis, marine zones were demarcated using geographical areas based upon Hammond et al. (2002).

\section{RESULTS}

A total of eight animals (7.9\%) demonstrated seropositivity with $T$. gondii antibody levels ranging from 8 IU mL $\mathrm{mL}^{-1}-250 \mathrm{IU} \mathrm{mL}^{-1}$ (Table). Sero-positive animals were recorded in three of the five marine zones from which samples were screened (Figure).

\section{DISCUSSION}

The majority of seropositive animals were shortbeaked common dolphins (Delphinus delphis) and seroprevalence data revealed the first ever documented Toxoplasma infection in a baleen whale species (humpback whale Megaptera novaeangliae). These findings represent the first $T$. gondii-seropositive cases from cetaceans in British waters and demonstrate that cetacean populations frequenting British waters are exposed to T. gondii at some stage, although the specific route of transmission has not yet been confirmed. It seems likely that infection in cetaceans is via $T$. gondii oocysts in contaminated water as these animals predominantly feed on fish, invertebrates and cold-blooded animals which would not be expected to support the tachyzoite and bradyzoite life-cycle stages of $T$. gondii. This is supported by seropositivity in a single humpback whale, as humpback whales are primarily planktivorous and piscivorous (Barros \& Clark 2002).

The humpback whale is generally understood to be a seasonal migrator with Northern Atlantic populations thought to have breeding grounds in the West Indies (Smith et al. 1999). Known feeding grounds exist in waters off Norway, Iceland, Greenland and Canada (Stevick et al. 2003). Humpback whales have been detected consistently between October-March from the Western 
TABLE

Animals tested and percentage occurrence of Toxoplasma gondii, including titer range (IU mL-1)

\begin{tabular}{|c|c|c|c|c|}
\hline Species & $\begin{array}{l}\text { Number } \\
\text { tested }\end{array}$ & $\begin{array}{l}\text { Number } \\
\text { positive }\end{array}$ & $\begin{array}{l}\text { Percentage } \\
\text { Occurrence }\end{array}$ & $\begin{array}{l}\text { Titer Range } \\
\text { (IU mL-1) }\end{array}$ \\
\hline \multicolumn{5}{|l|}{ Delphinus delphis } \\
\hline (Shot-beaked common dolphin) & 21 & 6 & 28.6 & $8-250$ \\
\hline \multicolumn{5}{|l|}{ Grampus griseus } \\
\hline (Risso's dolphin) & 1 & 0 & 0.0 & $<2$ \\
\hline \multicolumn{5}{|l|}{ Lagenorhynchus acutus } \\
\hline (Atlantic white-sided dolphin) & 1 & 0 & 0.0 & $<2$ \\
\hline \multicolumn{5}{|l|}{ Megaptera novaeangliae } \\
\hline (Humpback whale) & 1 & 1 & 100.0 & 8 \\
\hline \multicolumn{5}{|l|}{ Phocoena phocoena } \\
\hline (Harbour porpoise) & 70 & 1 & 1.4 & 125 \\
\hline \multicolumn{5}{|l|}{ Stenella coeruleoalba } \\
\hline \multicolumn{5}{|l|}{ Tursiops truncatus } \\
\hline \multicolumn{5}{|l|}{ Ziphius cavirostris } \\
\hline (Cuvier's Beaked Whale) & 1 & 0 & 0.0 & $<2$ \\
\hline
\end{tabular}

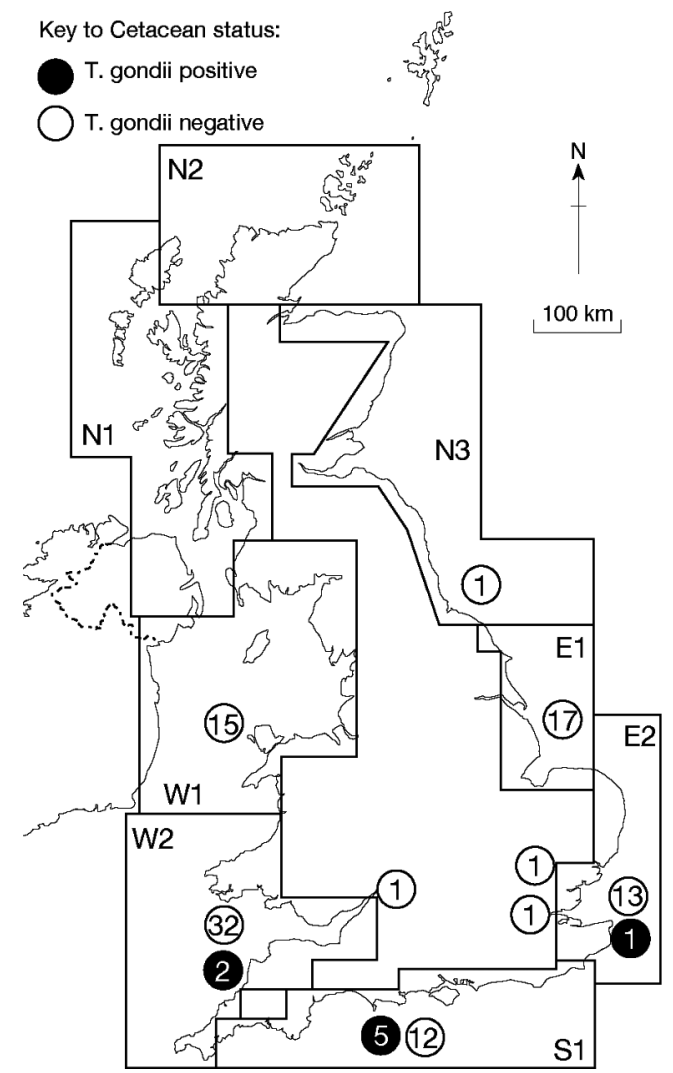

Outline map of UK and surrounding waters, number of Toxoplasma gondii sero-positive and sero-negative cetaceans found in each marine zone.

edge of the English Channel to the Western waters of the Shetland Islands (Charif et al. 2001). Postmortem examination indicated the infected animal in this study was a juvenile and the probable cause of death was starvation. The recovery location (Figure, Zone E2) is a consider- able distance from the closest known migratory route. It seems plausible this individual became disorientated during migration and accidentally entered the English Channel. The lack of productive food sources here could have lead to starvation. Since latent infections of T. gondii are know to affect behavior in other animals, the question arises as to what extent behavioral changes contributed on this occasion. It is recognized that this is only one of many possible explanations; but this raises concerns about the nature of the threat posed to marine species by $T$. gondii.

Many marine mammals inhabit coastal environments and most, with the exception of the planktivores and herbivores, occupy a high position in their associated food webs. Since much of their dietary intake is of commercial importance to humans they may be used as important sentinels of marine environmental health (Le Blanc 1997). Recent work in California (Miller 2002) associated T. gondii infection with mortality in Southern Sea Otters. Furthermore, sub-clinical toxoplasmosis has been linked with behavioral changes in both rodents (Webster et al. 1994) and humans (Yolken et al. 2001). As such it is conceivable that marine mammals may also undergo such changes and that these changes may have a direct impact on the fitness of the infected species concerned. We suggest that $T$. gondii seroprevalence should be routinely tested for in all postmortems of marine mammals from the UK and other national waters in order to provide an assessment of the potential risk from T. gondii infection in marine mammals.

\section{ACKNOWLEDGEMENTS}

To Paul Jepson and Rob Deaville (Institute of Zoology), for providing samples for this study.

\section{REFERENCES}

Barros NB, Clarke MR 2002. Diet. In WF Perrin, B Würsig, JMB Thewissen, Encyclopaedia of marine mammals, Academic Press, San Diego, p. 323-327. 
Charif RA, Clapham PJ, Clark CW 2001. Acoustic detections of singing humpback whales in deep waters off the British Isles. Mar Mammal Sci 17: 751-768.

Dubey JP, Zarnke R, Thomas NJ, Wong SK, Van Bonn W, Briggs M, Davis JW, Ewing R, Mense M, Kwok OCH, Romand S, Thulliez P 2003. Toxoplasma gondii, Neospora canium, Sarcocystis neurona and Sarcocystis canis-like infections in marine mammals. Vet Parasitol 116: 275-296.

Hammond PS, Berggren P, Benke H, Borchers DL, Collet A, HeideJørgensen MP, Heimlich S, Hiby AR, Leopold MF, Øien N 2002. Abundance of harbour porpoise and other cetaceans in the North Sea and adjacent waters. J Appl Ecol 39: 361-376.

Law RJ 1994. Collaborative UK marine mammal project: summary of data produced 1988-1992. Fisheries Research Technical Report, Ministry of Agriculture, Fisheries and Food, Directorate of Fisheries Research, Lowestoft, 42 pp.

LeBlanc GA, Bain LJ 1997. Chronic toxicity of environmental contaminants: sentinels and biomarkers. Environ Health Persp 105: 65-80.

Miller MA, Gardner IA, Kreuder C, Paradies DM, Worcester KR, Jessup DA, Dodd E, Harris MD, Ames JA, Packham AE, Conrad PA 2002. Coastal freshwater runoff is a risk factor for Toxoplasma gondii infection of Southern sea otters (Enhydra lutris nereis). Int J Parasitol 32: 997-1006.
Simpson VR 2002. Wild animals as reservoirs of infectious diseases in the UK. Vet $J$ 163: 128-146.

Smith TD, Allen J, Clapham PJ, Hammond PS, Katone S, Larsen F, Lien J, Matilla D, Palsbøll PJ, Sigurjóhnssen J, Stevick PT, Øein N 1999. An ocean-basin-wide mark-recapture study of the North Atlantic humpback whale (Megaptera novaeangliae). Mar Mammal Sci 15: 1-32.

Stevick PT, Allen J, Bérubé M, Clapham PJ, Katona SK, Larsen F, Lien J, Mattila DK, Palsbøll PJ, Robbins J, Sigurjøhnssen J, Smith TD, Øein N, Hammond PJ 2003. Segragation of migration by feeding ground origin in North Atlantic humpback whales (Megaptera novaeangliae). J Zool Lond 259: 231-237.

TRU - Toxoplasma Reference Unit 2007. Toxoplasma Cytoplasma Modifying Antibody Test (Dye Test). Toxoplasma Reference Unit, National Public Health Service for Wales, Singleton Hospital, Swansea, SA2 8QA, United Kingdom.

Webster JP, Brunton CF, MacDonald DW 1994. Effect of Toxoplasma gondii on neophobic behaviour in wild brown rats, Rattus norvegicus. Parasitol 109: 37-43.

Wong SY, Remington JS 1993. Biology of Toxoplasma gondii. AIDS 7: 299-316.

Yolken RH, Bachmann S, Rouslanova I, Lillehoj E, Ford G, Torrey EF, Schroeder J 2001. Antibodies to Toxoplasma gondii in individuals with first-episode schizophrenia. Clin Infect Dis 32: 842-844. 